\title{
LEGG ARTIKKELSAMLINGEN DIN I SKYEN
}

\author{
Har du mistet oversikten over hvor du la den fine oversiktsartikkelen du kom over mens du satt hjemme \\ og surfet? Eller har du lyst til å ha biblioteket med deg på nettbrettet?
}

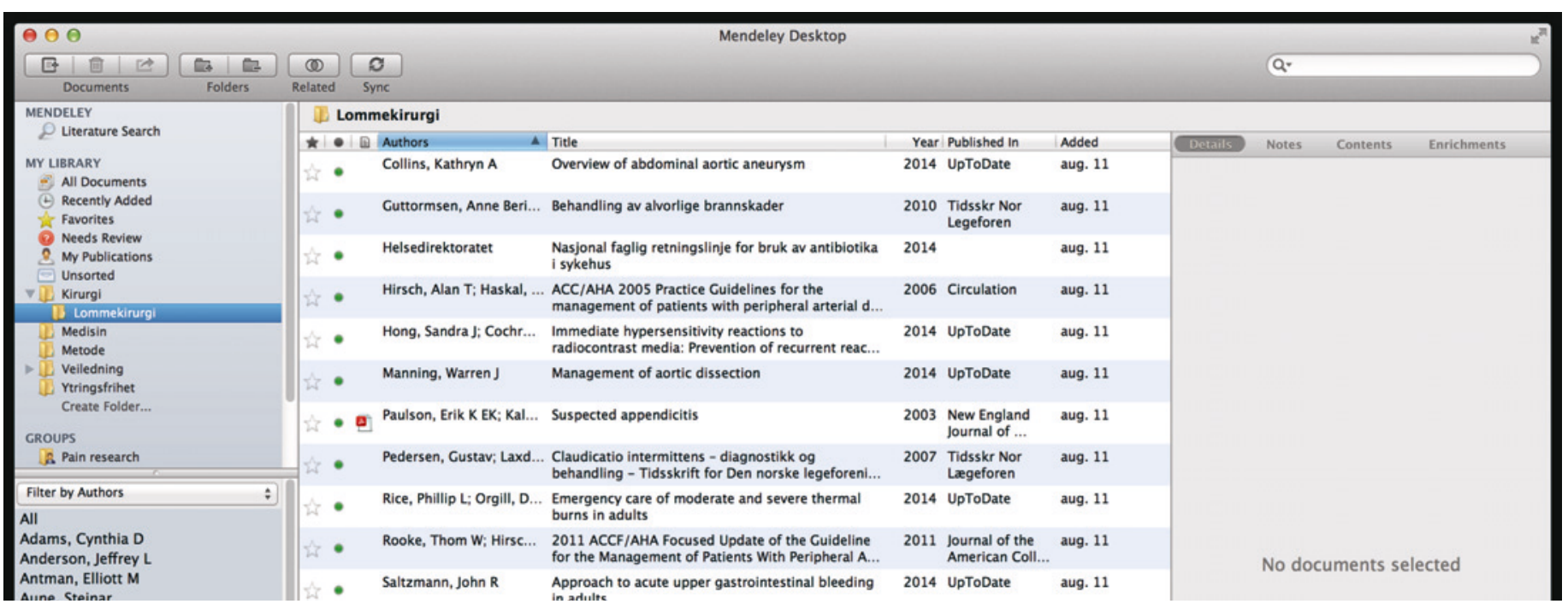

Programmet lager systemer på samme måte som andre referanseprogrammer, men gir den fordelen at du automatisk kan synkronisere referansene dine på tvers av datamaskiner og telefon/nettbrett og ha tilgang gjennom en nettside

Etter sommerens tips om hvordan du kan få bedre oversikt over forskningen som foregår (1), bugner kanskje datamaskinene dine av artikler som ligger uorganisert rundt omkring på harddiskene. Kanskje har du et referanseprogram på jobben, men får ikke systematisert artiklene eller kan hente dem opp hjemmefra.

Et moderne liv innebærer at det finnes en skytjeneste for forskere også. Mange av oss bruker allerede et tradisjonelt referanseprogram, men der ligger artikkelbiblioteket ditt lokalt på datamaskinen.

Referanseprogrammet Mendeley er et alternativ for å systematisere referanser. Det fungerer både som nettside, program til $\mathrm{Mac} / \mathrm{PC}$ og som app til Apple-produkter. Programmet er skybasert, og artikkelbiblioteket ditt synkroniseres automatisk mellom Kontor-PC, Hjemme-Mac og nettbrett. Dessverre finnes det ingen offisiell app til Android ennå. I tillegg til at det gir muligheter for å organisere artikkelsamlingen din, finnes det også siteringsmuligheter med siteringsstiler for de fleste tidsskrifter, inkludert Tidsskrift for Den norske legeforening.

En av de mest interessante funksjonene til den skybaserte tjenesten er det sosiale nett- verket rundt programmet. Gjennom grupper og forumer kan brukerne finne andre innen samme forskningsområde og dele artikler med dem. I tillegg kan man ha mer eller mindre private grupper, for eksempel i sin egen forskningsgruppe. Da kan alle legge ut artikler til gruppen, og så kan man lese, laste ned eller kommentere.

Programmet er gratis så lenge man har et normalt antall artikler i samlingen. Det kan erstatte programmer som EndNote og RefWorks.

\section{Ole Kristian Losvik}

Tidsskriftet

\section{Litteratur}

1. Losvik OK. Få oversikt over medisinske tidsskrifter. Tidsskr Nor Legeforen 2014; 134: 1385

\section{0}

forskere

bruker Mendeley 